\title{
Contesting Density: Beyond Nimby-ism and Usual Suspects in governing the future city
}

\author{
Jennifer Robinson \\ Department of Geography, University College London, \\ 26 Bedford Way, London, WC1H OAP, UK, jennifer.robinson@ucl.ac.uk \\ orcid.org/0000-0002-7716-4770
}

and

Katia Attuyer

Department of Urban Planning and Design, Xi'an Jiaotong-Liverpool

University, 111 Renai Road, Suzhou Dushu Lake Science and Education Innovation

District, Suzhou Industrial Park, Suzhou, 215123, China, katia.attuyer@xjtlu.edu.cn)

orcid.org/0000-0003-4731-6048

Density is often a major focus of contestation in imagining the future city. The built form of the future city, including its height and the extent of open space provision, is a crystallisation of current and projected urban growth, policy ambitions and political contestations. Also determinant of future built form are present capacities to extract value from the future income streams of urban development, on the part of both private and public actors. This tight 'nexus' of finance, policy, politics and interests drives the specific heights, densities and public space provision of the future city. The question of density opens out to many aspects of urban design and politics. In contesting density, then, what is it that urban residents are concerned with? This paper considers, on what grounds today's urban residents might be drawn into a battle for the quality of the future city? Governing the future city begins in these contemporary struggles. Exploring the co-existing temporalities of urban politics in the London case study discussed here refutes the conventional planning critique that contests over height and density are simply NIMBY-ist. This criticism obscures what our case study shows to be a generous cross-generational commitment to securing an inclusive urban future. Contestation of "density" speaks to concerns of residents today, but also speaks for residents of the future. Residents' groups look to protect the quality of the future built environment, 
to ensure the accessibility of housing to the poorest, and to make a city which is liveable across the generations. These are struggles for the democratic governance of the future city.

In a large-scale plan-led development in Old Oak, North-west London, associated with major national transport infrastructure (a high-speed train to the North, HS2, and a cross-London rail-line) significant public contestations have arisen, concerned with high housing targets for the development which would yield a new high-rise typology for London. In this future neighbourhood, densities would far exceed existing city-wide norms. Two related trends are shaping such densification of London's built form. The first is longstanding developer interest in maximising value extraction (Flynn, 2016) but also more recent models of construction which can meet the needs of financialised investors (Guironnet et al., 2014). The second is a direct consequence of the withdrawal of state investment from urban development. This has initiated a compensatory pressure to extract value from the built environment, now the primary (if not only) source of state contributions to transport and social infrastructure for new developments (Robinson and Attuyer, 2020). The idiosyncratic territorially delimited nature of how the state captures value from development in London (each development must yield sufficient profit to pay for its own infrastructure) and the limited nature of the development taxes (planning gain negotiated on a one-off basis at the moment of construction) strongly intensifies the push to achieve greater densities to secure enhanced income streams. The high infrastructure costs (at least $f 1.82$ billion) of developing the Old Oak area (with fragmented former industrial and railway lands and complex levels) place a stringent burden on this value extraction process (OPDC, 2015). Further, predicted population increases and a lengthy period in which especially social housing provision has fallen far short of need, mean there is now strong political pressure to deliver more houses of any kind, leading to highly ambitious and untested targets being set for delivery in certain "Opportunity Areas", of which the Old Oak area is one (Just Space, 2018).

Across London, these combined forces have created significant pressure on the built environment, leading to a rapid growth of high rise and dense developments (NLA, 2018). This 'nexus' of housing targets, finance and building heights yields propositions for urban development which have instigated sustained and determined opposition from residents across the city, including in Old Oak (Just Space (www.justspace.org); Watt and Minton, 
2016). Both conventional planning theory and practitioners too easily dismiss this community mobilisation as involving "the usual suspects" or representing a narrow interest base. The question is often, how to manage community participation so development can proceed (Sims and Bosetti, 2016), or how to sidestep contestation through incorporation and superficial consultation (Beebeejaun, 2018). In this case study, we rather identify such community-based groups and residents as collaborative, creative and critical actors, whose interests stretch from protecting their "place" or neighbourhood from the dis-benefits of new developments, including threats to quality of life or modest property values, to futureoriented concerns for social infrastructure, welfare, inclusion and the housing and employment needs of the poorest. They foreshadow an expansive public vision of a future city.

\section{"What is the problem with tall buildings?"}

"The densities there are very, very high and have rarely been achieved in London." (Architect ${ }^{1}(A) 2$ and 4)

"The biggest argument with the public is about density, density and height." (Planning Committee (PC) 1)

"we want to try and make sure it isn't too much of a monolithic, big, tall place that perhaps people don't want to live, try to keep it a human type of scale." (Community Representatives (CR) 2 and 3).

As the day's proceedings of the Old Oak Park Royal Development Corporation (OPDC) Local Plan Evidence in Public hearing drew to a close in April 2019, the Planning Inspector looked around for a member of the residents' group who had been speaking to issues of sustainability during the day. She had rushed off to fetch her kids from school, so the Inspector shared with me (Jenny) the image he had found on his phone, of a distinctive high rise building in Australia,

\footnotetext{
${ }^{1}$ All interviews undertaken by the authors between July 2015 and July 2017.
} 
with green and open space on upper storeys, complete with trees, and cladding covered in vegetation. A lot of the discussion during the day, in which the Local Plan was being assessed for regulatory compliance, had been quite technical - how can heating and cooling challenges of high rise buildings be taken into account in policy (this is what the resident had been addressing); how can sufficient accessible open and public space and play space be provided in dense configurations of very tall buildings; do the additional costs of high rise construction undermine the scope for social housing - and the killer question: why are there such high targets for housing provision that the only solution is to build at densities beyond those of the financial district in central London? In this more relaxed moment with the Inspector, a fascination with the potential for creative and interesting new designs for this future part of London surfaced. Such a hopeful pull to creating a future appealing city had already emerged in our interviews with architects and developers working on individual building or area designs (A2, A4; Developer (D) 5). And it underpinned moments of collaboration between residents and planners around the theme of "place-making", who had to some extent built shared understandings of the potential in the natural landscape and in the built heritage and history of the area (PC 2; OPDC Officer (OO) 1, 4; CR2 and 3, CR4). Quite some synergies were evident between community visions and emerging planning policy (GUA, 2015).

But as specific proposals for individual developments came forward in planning applications, design initiatives were strongly criticised by local residents as offering a thin veneer (literally, as "good design" often referred to the use of bricks as cladding) on oversized and overbearing buildings proposed for inappropriate locations. Minimal or even non-policy compliant social infrastructure was a common feature, with very little contribution to the costs of providing for the needs of a new community or yielding benefits for existing residents. For some planners and developers these concerns were quickly dismissed:

"what's the community? You know because to be honest the community that engages in planning applications is a very narrow section of middle-aged, middleclass people ... with a particular political view generally ... these people are not representative..." (Local Authority Executive Director). 
"there has been a whole range of consultation events. It tends to be the local worthies and people in the know who tend to attend, rather than just the ordinary person on the streets." (PC4)

For planners and political decision-makers, strategic issues of national development, transport infrastructure and connectivity, as well as wider housing need which would be met by the planned development, seem to place existing residents' concerns as parochial (PC1; 002). However, as we will see below, the residents were well aware of these strategic issues (which were in fact also strongly political, as overall housing numbers were prominent on the Mayor's election platform). Residents placed other strategic issues on the table, but issues on which both the Mayor and the planning authority were willing, under pressure of targets and finances, to cut corners: quality of the built environment; policy compliance; affordable housing; green and open space; environmental sustainability; air quality. Not just addressing "local" concerns, as planners suggested, the residents' groups were asking, what kind of future city was going to be built?

The London Tenants' Federation, in collaboration with Just Space, a community-based network engaging in metropolitan planning issues, built a mutual support network, the Grand Union Alliance, across the extensive Old Oak development area to encourage engagement in the planning process (Hayward, 2020). Since 2014, over 200 groups and individuals divided across three London boroughs, and to some extent separated by the relatively unpassable rail and industrial lands they lived amongst, had been attending community meetings, submitting consultation responses, and engaging with developers and planners. The nature of these neighbourhoods and the challenges they had faced over some time (not least engaging with HS2 and contesting a concentration of recycling plants in the area) meant that those involved did not conform to the "usual suspects" stereotype. Participants in the network came from different ethnic backgrounds, included those busy raising young families, working class and professionals, newcomers as well as people who had lived in and been active in residents' associations in the area for decades. Two local neighbourhood forums (which have a legal status to bring forward neighbourhood level plans) were constituted within and adjacent to the development area, and residents were also busy contesting HS2 planning processes. This engagement was at times onerous to the point of exhaustion: "every single day was a 
meeting; and that is how is has been for the last two years" (CR1). Given the long-term nature of large-scale developments, residents' groups were often acting out of a more general sense of interest, citizenship and philanthropy: "You talk about the next generation's benefits and so on, which is the only way you can put it, really. "Oh, I'll be dead by then," sort of thing." (CR7).

What were their concerns with density then? Was it that they were acting in their own selfinterest, to protect themselves against high buildings? Certainly, there was a strong concern amongst homeowners close to the anticipated rail station and core development area that their properties were now valueless and redlined by banks, reminiscent of the US suburban "politics of turf" (CR10; Cox and McCarthy, 1984). There was also widespread concern amongst middle class and older residents that their neighbours who might have not spoken English well, were financially struggling, or had health and mobility issues, would be very badly affected by the developments, including extended closure of roads, restricted access to hospitals and overcrowding of services (CR1; CR10). Other issues which had a direct personal impact on existing residents concerned sunlight and daylight being blocked by tall buildings. For planners, though, the challenge was to minimise impacts while not preventing development: "You know, if a site is very close to existing residential properties and the orientation of the site is such that any development on the site would have an impact on those properties then if the alternative is not to develop the site at all, then you know we have to find a way of making it happen whilst minimising that impact." (0O2). For some architects and planners, these adverse impacts of tall buildings were simply the reality of developing in already built-up London (0O4; A5). But the community network, the GUA (2019, D5 Tall Buildings), sought to insert wording in the local plan to indicate that tall buildings should cause no harm and minimise dis-amenity to surrounding areas. A source of great tension between the planners and residents' groups was that areas near to existing residential neighbourhoods, or to heritage assets had originally (in the first draft local plan) been seen as "part of 'sensitive locations' that were to be respected and reflected in lower densities and buildings of more restrained height that related more to their surroundings. But now it is proposed that buildings of 16 storeys and above are appropriate. This is a regressive change." (GUA, 2019, D5). 
The more general question of access to facilities weighed heavily on the minds of many residents. If high rise and dense developments made little provision for social facilities including schools, hospitals and doctors, which were already overcrowded in the area, this presented challenges for both current and future residents. The explicit strategy of encouraging early developments to come forward before any new transport infrastructure was in place risked exacerbating transportation difficulties ranging from overcrowding on buses and trains, traffic gridlock as a result of industrial traffic and resultant air quality issues (CR1, CR7). Residents had concerns that plans to focus early developments on student housing and rental accommodation, both forms of high-rise profitable in the more risky early stages of the development, would lead to a transient community which placed pressure on services but did not contribute to the place making and stability of the neighbourhoods. This experience was familiar to residents from existing concentrations of high rise and dense development, primarily student housing, in the southwest corner of the development area (CR1). Valued local facilities (small pubs or cafes, minor heritage elements, such as vernacular industrial heritage building) as well as affordable business premises providing around 6500 local jobs were all under threat from the high values which even relatively small sites might yield.

As the OPDC shifted from policy proposals to implementation, they made a more determined effort to leverage government investment and capture a higher share of planning gain incomes to fund the development. The density and height ambitions of the OPDC were ramped up to secure adequate funding. But the extent of these ambitions was also occluded in representations of the plans. Both the pressure to encourage increased height and density and the seemingly deceptive planning statements drew strong criticisms from residents. A statement on Tall Buildings, for example, only discussed "shoulder and platform" heights and completely avoided any discussion of actual heights of towers or anticipated densities across the development. The Old Oak neighbourhood forum indicated that these were "extreme and unprecedented densities" ${ }^{2}$. Resident's concerns intensified about the adverse consequences of very tall buildings for delivering wider social benefits. Tall buildings are expensive to build

\footnotetext{
2 rep-82-100-

001_henry_peterson_obo_st_quintin_and_woodlands_neighbourhood_forum_and_old_oak_park_neighbour hood_forum_statement_on_matter_4.pdf
} 
above a certain height and so are generally associated with very high end and expensive housing units (Mayor of London, 2017, p. 20). By contrast, Harlesden Neighbourhood Forum (2017) and other residents' groups argued for much higher levels of affordable housing, stating that Harlesden ward, bordering to the immediate north of the OPDC, was one of the 10 most deprived wards (out of over 628) in London. Local jobs to address unemployment and poverty were also of concern (CR6). The residents pointed out the environmental challenges of tall buildings in terms of overheating, wind tunnels, recycling and air quality. They argued that densification would lead to lack of provision of adequate accessible public space, and were concerned about the routine provision of play space on roofs and podiums. This was a common feature of all the early developments, and a clear expectation of OPDC plan policy (OPDC, 2018a, Policy D9; OPDC 2019, PR10), even though this did not conform with wider London Plan policy expectations that play spaces should be accessible, integrated into wider neighbourhoods, and overlooked for security.

The OPDC argued that the "identified homes and jobs capacity can be delivered whilst meeting or exceeding other policy requirements relating to environmental performance and quality of place" ${ }^{3}$ However, in ramping up the densities, possibilities for less than policy compliant buildings and public spaces were being proposed, including extensive off-site provision of some services (OPDC, 2019). Planning gain guidance brought forward some innovative practices to safeguard the interests of the planning authority. This included regular review of the profitability of developments as they progressed to ensure enhanced state benefit; and controls over the selling on of rental properties as these would have accrued less planning gain than properties built for private sale. The OPDC proposed robust processes to secure developer contributions to meeting the wider costs of the development but, following the Mayor's emerging policy, as a priority, this was to be directed to infrastructure provision rather than to social needs or environmental sustainability (Mayor of London, 2019, DF1D).

\footnotetext{
${ }^{3}$ opdc_response_to_matter_4 (1.15), OPDC Local Plan EIP
} 
In contesting density, Old Oak residents put their finger on the key dynamics of urban development in London, and why outcomes have been so controversial: the "nexus" of loosely set housing targets to meet political objectives and the promotion of densities and heights which press the built environment into the service of state finances to pay for the development. Opening up "density" to bring into view these wider issues offers a different perspective on the residents' mobilisation. We suggest there are strong reasons to take the residents' concerns seriously, and not write them off as NIMBY's, or a narrow, sectional constituency concerned only with defending personal and present gain. Rather, our analysis of the OPDC development has emerged alongside a committed group of residents, eager to protect their wider communities, and concerned with the fate of future London residents. Taking their concerns seriously, we arrive at sharp insights into the endemic, structural forces which are guiding the future city in unsustainable, unliveable, "nasty" (CR1) directions. And this is not, in the end, to do with "density" or "height" as such, but with the combined extractive ambitions of planning authorities and developers which press on the built environment. Even for some developers the density demands and policy corner cutting was seen as not satisfactory - build to rent developers with a bespoke model based on certain financial and market considerations found it hard to meet the planners' demands for increased height and quantity of units; and those concerned to protect their reputations felt that building at these heights and densities might compromise the quality of their product (D5; Anonymous Developer).

So rather than "height" or "density" per se, residents oppose the willingness to trade off significant policy commitments to social and environmental needs against heightened income generation from the built form. They have pointed precisely to the tangled "nexus" of targets, finance and heights, which is driving poor outcomes across the city, and which demands urgent political and policy response. Future research on density, then, by planners and

\footnotetext{
${ }^{4}$ The Inspector at the OPDC Local Plan EIP coined this phrase in his introduction to discussion of Matter 4: Density, Intensity, Heights and Targets. https://www.london.gov.uk/sites/default/files/id-

11 opdc hearing agenda session 4.pdf
} 
practitioners as well as scholars, might attend more closely to residents' concerns with liveability, and interrogate the sharp economic interests which press the built environment into service for value extraction. This stretches beyond any easy assignment of blame to developers or global processes of financialisation. It requires nuanced assessment of the "nexus" of processes in particular contexts which govern how the economic and social value realised through building the future city is distributed not only across different actors, but between the present and the future. In mobilising to defend the quality of urban life and access to the city in the present, residents' groups contest the nature of the future city. Governing the future city, the city yet to come, begins, then, with these contestations on behalf of residents who are not yet there.

\section{Acknowledgements}

The authors acknowledge funding from the ESRC Urban Transformations Grant (number $\mathrm{ES} / \mathrm{N} 006070 / 1)$ 'Governing the future city: a comparative analysis of governance innovations in large scale urban developments in Shanghai, London, Johannesburg', with Phil Harrison (University of the Witwatersrand) and Fulong Wu (University College London). We are very grateful for the support we received from Sharon Hayward from the London Tenants' Federation, our partners in the research project), Robin Brown of Just Space, and members of the Grand Union Alliance and Old Oak Neighbourhood Forum. We thank all interviewees and informants, who generously shared their experiences and challenges with us. We also thank the officers of the OPDC and members of the OPDC planning committee and board for their openness about and insight into their work. Any errors or omissions remain our responsibility.

\section{References}

Beebeejaun, Y. 2018. Public Participation and the Declining Significance of Planning, in J. Tomaney and J. Ferm (eds.), Planning Practice: Critical Perspectives from the UK. London: Routledge, Chapter 6. 
Cox, K. and McCarthy, J. 1982. Neighbourhood activism as a politics of turf. In Conflict, politics and the urban scene. Eds Cox, K. and Johnson, R. Harlow, UK: Longman.

Flynn, J. 2016. Complete control: Developers, financial viability and regeneration at the Elephant and Castle, City, 20:2, 278-286.

Grand Union Alliance (GUA). 2015. Community-Based Vision and Objectives. Accessed 2 April 2020. https://cc8f0490-0bd7-4856-b03bc3a1765403dc.filesusr.com/ugd/4e0a01_c1b57dfeb646429c9f9f2e054d9c9c5b.pdf

Grand Union Alliance (GUA). 2018. Response to the OPDC's revised draft Local Plan regulation 19(2) made on 30th July 2018. A summary is available at (accessed 2 April 2020): https://www.london.gov.uk/moderngovopdc/documents/s58522/Item\%2011c\%20\%20Appendix\%20B SCI\%20Statement\%20of\%20Consultation.pdf

Guironnet, A, Attuyer, K, Halbert, L (2016) Building cities on financial assets: The financialization of property markets and its implications for city governments in the Paris city-region. Urban Studies 53(7): 1442-1464.

Harlesden Neighbourhood Forum. 2017. Regulation 19 Consultation, July-September 2017, Harlesden Neighbourhood Forum Response.

Hayward, S. 2020. Community engagement in planning in London's Large-Scale Developments. Draft, available from the authors.

Just Space, 2018. Draft New London Plan: Submission to Consultation Process. https://justspacelondon.files.wordpress.com/2018/02/just-space-on-new-london-plancomplete.pdf. Accessed 10 March 2020.

Mayor of London, 2017. Draft New London Plan Viability Study. Accessed 2 April 2020 at: https://www.london.gov.uk/sites/default/files/london_plan_viability study dec 2017.pdf 
Mayor of London, 2019. Draft New London Plan (post-consultation). City Hall.

https://www.london.gov.uk/sites/default/files/intend to publish - clean.pdf. Accessed 10 March 2020.

New London Architecture. 2018. London Tall Buildings Survey 2018.

Old Oak and Park Royal Development Corporation (OPDC), 2015. Development Infrastructure Funding Study. Accesses 10 September 2018 at:

https://www.london.gov.uk/sites/default/files/final_old_oak difs 141015 new cover.pdf

Old Oak Park Royal Development Corporation (OPDC). 2018a. Local Plan Second Revised Draft for Regulation 19 (2) Consultation 14 June 2018. OPDC: City Hall, London. Accessed on 12 September 2018 at:

https://www.london.gov.uk/sites/default/files/opdc local plan 2018.pdf

Old Oak Park Royal Development Corporation (OPDC). 2018b. Old Oak North Development Framework Principles, Local Plan Supporting Study 32, Consultation June 2018. OPDC: City Hall, London. Accessed on 12 September 2018 at:

https://www.london.gov.uk/sites/default/files/32. old_oak north_development framewor k_principles 1.pdf

Old Oak Park Royal Development Corporation (OPDC). 2018c. Tall Buildings Statement. Last Accessed 2 April 2020:

https://www.london.gov.uk/sites/default/files/52._tall_buidings_statement 2018.pdf

OPDC 2019. Planning Obligations: Supplementary Planning Document. Draft for Public Consultation. 10 January 2019. Accessed 2 April 2020 at:

Robinson, J. and Attuyer, K. 2020. Extracting Value, London Style: Revisiting the role of the state in urban development. Under review. 
Sims, S. and Bosetti, N. 2016. Stopped: Why people oppose residential development in their back yard. Centre for London.

Watt, P. and Minton, A. 2016. London's housing crisis and its activisms, City, 20:2, 204-22 